\title{
Impact of the toxic dinoflagellate Alexandrium catenella on Pacific oyster reproductive output: application of flow cytometry assays on spermatozoa
}

\author{
Nelly LE Goïc ${ }^{1, a}$, Hélène HÉGAReT ${ }^{1}$, Caroline FABIouX ${ }^{1}$, Philippe MineR ${ }^{2}$, Marc SuQuET ${ }^{2}$, \\ Christophe LAMBERT $^{1}$ and Philippe SOUdANT ${ }^{1}$ \\ ${ }^{1}$ Laboratoire des Sciences de l'Environnement Marin (LEMAR), IUEM-UBO, Technopôle Brest Iroise, Plouzané, France \\ ${ }^{2}$ Laboratoire de Physiologie des Invertébrés (LPI), IFREMER, Technopôle Brest Iroise, Plouzané, France
}

Received 23 November 2012; Accepted 10 January 2013

\begin{abstract}
The toxic dinoflagellate Alexandrium catenella recurrently blooms on the coasts of France and produces Paralytic Shellfish Toxins (PSTs) that accumulate in bivalves. These toxins can affect various physiological functions including reproduction. The present study aims to validate measurements of sperm viability, DNA content and mitochondrial membrane potential in Pacific oyster Crassostrea gigas using flow cytometry coupled with fluorescent markers, and to use these measurements to assess the cellular parameters of sperm from Pacific oysters exposed to A. catenella. These parameters may influence fertilization, embryogenesis and larval development in free-spawning shellfish. Sperm viability and DNA content estimation were assessed using SYBR-14, which only penetrates cells with intact membranes. Cell mortality was measured with propidium iodide (PI), which penetrates cells with membrane damage. Mitochondrial membrane potential, used as an estimate of mitochondrial function, was measured using JC-1 dye, which selectively enters into mitochondria and reversibly changes colour from green to orange as the membrane potential increases. To assess the effect of toxic algae on oyster sperm, broodstock (ripe oysters) were fed toxic ( $A$. catenella) or non toxic (Heterocapsa triquetra) dinoflagellates at $250 \mathrm{cell} \mathrm{m}^{-1}$ for 9 days. After this exposure period, mature oysters were stripped and cellular responses of sperm analysed. Average DNA staining, as measured by SYBR14, appeared lower and more variable in gametes from A. catenella-exposed oysters than in those from control oysters fed $H$. triquetra. Additionally, mitochondrial membrane potential of sperm from A. catenella-exposed oysters was significantly higher ( 1.5 fold) than that of sperm produced by oysters fed H. triquetra. Both the increase of mitochondrial membrane potential and the modification of DNA structure can be expected to impact spermatozoa ability to fertilize oocytes and could thus impact related reproductive processes.
\end{abstract}

Keywords: Harmful algal bloom / Sperm quality / Cellular parameters / Flow cytometry / Pacific oyster / Crassostrea gigas / Alexandrium catenella

\section{Introduction}

The dinoflagellate Alexandrium catenella (Whedon and Kofoid) was first described in 1936 and is now distributed worldwide. A. catenella produces the paralytic shellfish toxins (PSTs) known as saxitoxin (STX) and derivatives (Anderson et al. 2012). These toxins accumulate in bivalves and can cause numerous human illnesses, sometimes even death, after consumption of contaminated shellfish. In France, recurrent toxic A. catenella blooms have occurred since 1995 in Thau lagoon (Lilly et al. 2002). Blooms of A. catenella can have a major economic impact on shellfish farming, as detection of PSTs has resulted in recurrent harvest closures (REPHY monitoring data, Ifremer).

\footnotetext{
a Corresponding author: nelly.legoic@univ-brest.fr
}

Harmful algal blooms (HABs) such as those of A. catenella can affect bivalve physiology (Navarro and Contreras 2010; Hégaret et al. 2012). Because bivalves spawn their gametes into the surrounding water, reproductive output could be directly affected by different environmental pollutants (Favret et al. 2010; Akcha et al. 2012) or HABs (Erard-Le Denn et al. 1990; Leverone et al. 2006; Basti et al. 2011) found there. Cellular parameters of gametes can therefore be used as bio-indicators of modification and disturbance of the environment (Akcha et al. 2012). Alterations induced by noxious compounds have been observed in oyster gametes (Nice 2005). Pacific oyster (Crassostrea gigas) sperm exposed to Alexandrium minutum also showed a lower motility and ATP content, compared with unexposed cells (Haberkorn et al. 2010). More recently, Heterocapsa circularisquama has been 
shown to reduce activity rate and swimming velocity of spermatozoa of Japanese pearl oyster, Pinctada fucata martensi (Basti et al. 2013). Several studies have also reported recruitment failure of various bivalve species following HABs (Granmo et al. 1988; Summerson and Peterson 1990; Leverone et al. 2006; Bricelj and MacQuarrie 2007; Tang and Gobler 2009), suggesting a potential impact on gamete quality. Indeed, reproductive output and success is at least partially dependent on gamete quality, as it can influence fertilization, embryogenesis and larval development in free-spawning shellfish (Lewis and Ford 2012). Although high individual variability in reproductive success is partly attributed to gamete quality, research devoted to gamete quality in shellfish is limited, especially concerning the impact of HABs.

Assessment of sperm quality is usually based on the determination of spermatozoa number, morphology and motility, evaluated by light microscopy. Recent developments in flow cytometry methods have enabled more accurate and rapid analysis of sperm attributes in terrestrial and aquatic vertebrates (Gillian et al. 2005; Franco et al. 2011). A number of sperm characteristics related to fertilizing capacity (viability, acrosomal integrity, mitochondrial function, DNA/chromatin integrity and ROS production) can be accurately and rapidly measured using flow cytometry coupled with fluorescent markers (Cordelli et al. 2005, Gillan et al. 2005). These measurements have mainly been developed in vertebrates, but very few attempts have been made to apply these methods to the assessment of sperm in bivalves (Adams et al. 2003; PaniaguaChavez et al. 2006; Favret et al. 2010; Haberkorn 2010).

Rapid and efficient measurements of sperm morphological and functional characteristics by flow cytometry are not only relevant for shellfish aquaculture but also for ecotoxicological studies. Assessment of sperm cellular characteristics in cultivated and "exploited" areas could serve as a complementary tool for predicting reduced or unsuccessful recruitment sometimes observed in the field (Granmo et al. 1988; Summerson and Peterson 1990; Leverone et al. 2006; Bricelj and MacQuarrie 2007; Tang and Gobler 2009).

In the present study, we developed and validated flow cytometric protocols to measure oyster sperm viability, DNA content and mitochondrial membrane potential. These validated flow cytometric assays were then applied to assess cellular characteristics and functioning of spermatozoa stripped from Pacific oyster previously exposed to A. catenella.

\section{Materials and methods}

\subsection{Validation of flow cytometric assays on Pacific oyster sperm}

\section{Oyster sperm}

Spermatozoa were collected by stripping Pacific oyster gonads, and resuspended in filtered sterile sea water (FSSW). Samples of gametes were checked under a light microscope for mobility, and motile sperm from all samples were used in the experiments.

\section{Flow cytometric analysis}

Analysis of viability and mitochondrial membrane potential were performed using a FACSCalibur flow cytometer (BD Biosciences) and an EasyCyte Plus cytometer (Guava Merck Millipore), both equipped with standard optics and a $488 \mathrm{~nm}$ argon laser. Fluorescence is given in arbitrary units.

\section{Sperm viability}

Viability was measured using dual staining with SYBR-14 and propidium iodide (PI) (Live/Dead ${ }^{\circledR}$ Sperm Viability kit, Molecular Probes). An aliquot of $200 \mu \mathrm{l}$ sperm diluted at $1 \times$ $10^{6}$ cell ml ${ }^{-1}$ in FSSW was stained with both SYBR-14 (final concentration $1 \mu \mathrm{M}$ ) and PI (final concentration $10 \mu \mathrm{g} \mathrm{ml}^{-1}$ ) for $10 \mathrm{~min}$ in the dark, $18{ }^{\circ} \mathrm{C}$. Proportion of live cells was estimated with SYBR-14, which only penetrates cells with intact membranes, and emits in the bright green wavelength $(516 \mathrm{~nm}$, FL1 detector). Cell mortality was measured with PI, which penetrates cells with membrane damage and then emits in the red wavelength (617 nm, FL3 detector). Dying cells are stained with both SYBR-14 and PI. Results were expressed as percentages of live, dying and dead cells. Values from FSC (Forward scatter: relative cell size) and SSC (Side scatter: relative cell complexity) detectors were also acquired to estimate morphologic parameters of live cells.

\section{Preparation of different ratios of live and dead sperm}

To calibrate viability assessment, five percentages $(0,25$, 50,75 and $100 \%$ ) of live spermatozoa were prepared by dilution between live and dead cells using sperm obtained from 6 males. Dead spermatozoa of each male were obtained by freezing at $-80^{\circ} \mathrm{C}$ for $1 \mathrm{~h}$. Each sample was stained with both SYBR-14 and PI, and viability measured by flow cytometry.

\section{DNA content estimation}

DNA content of sperm cells was estimated with green fluorescence of SYBR-14, which binds DNA. This fluorescence was detected on the FL1 detector at $516 \mathrm{~nm}$ by flow cytometry. SYBR-14 fluorescence was observed on live sperm.

\section{Sperm mitochondrial membrane potential (MMP)}

Mitochondrial membrane potential was measured using the potential-dependent J-aggregate-forming delocalized lipophilic cation 5,5',6,6'-tetrachloro-1,1',3,3'-tetra-ethylbenzimidazol carbocyanine iodide (JC-1, Interchim FP-52314A). $\mathrm{JC}-1$ is a dye that can selectively enter into mitochondria and reversibly change colour from green to orange as the membrane potential increases. The monomer form predominates in mitochondria with low membrane potential and emits in the green wavelength $(525-530 \mathrm{~nm}$, FL1 detector) while the aggregate form accumulates in mitochondria with high membrane potential and emits in the high orange wavelength (590 nm, FL2 detector). MMP of active cells is 
estimated by the ratio of aggregate: monomer, i.e., orange: green fluorescence ratio. As the application of JC-1 for MMP assessment has not yet been validated for mitochondrial activity of sperm from marine organisms, we used CCCP (carbonyl m-chlorophenylhydrazone) as an inhibitor and caffeine as an activator of MMP. CCCP is known to reduce the mitochondrial inner membrane potential as an uncoupler and thus to inhibit mitochondrial ATP production (Mukai and Okuno 2004). Caffeine is a methylxanthine that inhibits c-Ampphosphodiesterase activity at high concentrations. This inhibition produces an increase in the intracellular levels of adenyl cyclase-cyclic adenosine $3^{\prime}, 5^{\prime}$-monophosphate (cAMP), a second messenger that raises sperm motility and stimulates sperm capacitation in Pacific oysters (Dong et al. 2002). Accordingly, samples were exposed to $100 \mu \mathrm{M}$ of the inhibitor CCCP (Sigma C-2759), or to $10 \mathrm{mM}$ of the activator caffeine (Sigma C-0750).

Aliquots of $200 \mu \mathrm{l}$ of the sperm samples at $1 \times 10^{7}$ cell ml $^{-1}$ were stained with JC-1 (final concentration $5 \mu \mathrm{M}$ ) for $10 \mathrm{~min}$ in the dark at $18{ }^{\circ} \mathrm{C}$, with or without CCCP or caffeine. To allow the dye to reach its distribution equilibrium in the mitochondria, $50 \mu \mathrm{l}$ of cells previously stained with $\mathrm{JC}-1$ were diluted 10 times in FSSW +/- CCCP/caffeine and analyzed by flow cytometry. No toxicity of CCCP or caffeine was observed on spermatozoa at concentrations used, as $97 \%$ of cells were observed to be alive after each treatment (data not shown).

\subsection{Morphological and functional characteristics of spermatozoa stripped from Pacific oysters exposed to Alexandrium catenella}

\section{Algal exposure}

Pacific oysters were acclimated for 4 days with $20 \mathrm{ml} \mathrm{min}-1$ of a mixture of Isochrysis sp., Tahitian clone (T. Iso) and Chaetoceros neogracile (cell ratio 1:3) at $10^{5} \mathrm{cell} \mathrm{ml}^{-1}$ total. Both algae were harvested in the exponential growth phase (4-5 days) for the acclimation. After acclimation, oysters were continuously exposed to either the toxic Alexandrium catenella (Whedon and Kofoid 1936) Balech, 1985 (ATTL01) or the non toxic dinoflagellate Heterocapsa triquetra (strain HT99PZ-Ehrenberg 1840) for 9 days at 250 cell ml $\mathrm{m}^{-1}\left(20 \mathrm{ml} \mathrm{min}^{-1}\right)$. The concentration of A. catenella used here was realistic compared to those encountered in Thau lagoon (Collos et al. 2004). Cultures of A. catenella and $H$. triquetra were grown in 10 -L carboys at $20^{\circ} \mathrm{C}$, with $24 \mathrm{~h}$ light at $100 \mu \mathrm{mol}$ photon $\mathrm{m}^{-2} \mathrm{~s}^{-1}$ in filtered sea water supplied with L1 medium (Guillard and Hargraves 1993). Digestive glands of oysters fed with A. catenella were analysed for toxin accumulation after exposure. Exposed oysters contained $14.5 \pm 11.2 \mu \mathrm{g} \mathrm{eq} \mathrm{STX} \mathrm{g}^{-1}$ (mean $\left.\pm \mathrm{CI}\right)$. Such individual variability is consistent with previous experiments in our laboratory (Haberkorn et al. 2010, 2011).

\section{Sperm analysis}

After 9 days of exposure, spermatozoa were collected, as described above, from six oysters fed A. catenella and ten oysters fed $H$. triquetra. Sperm cellular parameters were assessed using flow cytometry for viability, DNA content and MMP.

\subsection{Statistical analysis}

Statistical analyses were performed using STATGRAPHICS ${ }^{\circledR}$ software. To compare the effects of treatments (CCCP, caffeine, A. catenella exposure) on the different cellular parameters, $t$-tests were performed. Results were considered significant when $p$-value was $<0.05$.

\section{Results and discussion}

\subsection{Validation of flow cytometric assays on Pacific oyster sperm viability}

Viability is a key determinant of sperm quality. SYBR-14 and PI double staining is the most commonly used assay to measure sperm viability in both vertebrates and invertebrates (Paniagua-Chavez et al. 2006; Favret et al. 2010). This dual staining was firstly developed on mammalian sperm to assess viability (Garner et al. 1994; Thomas et al. 1998) before being used for marine organisms (Flasjshans et al. 2004). SYBR-14 was used to identify live cells as it is an acylated membrane loading dye. On entering the living cell, this membranepermeable DNA binding probe is deacylated by intracellular esterases. The deacylated fluorescent probe cannot then diffuse out of the cell back over the plasma membrane but stains the sperm nucleus. In sperm with deteriorated plasma membranes, SYBR-14 will leave the cell (Silva and Gabella 2006). As sperm die, they lose their ability to resist the influx of the membrane-impermeant dye PI, which apparently replaces or quenches the SYBR-14 staining upon entering (Garner and Johnson 1995).

Using SYBR-14 and PI double staining, three different sub-populations of sperm were distinguished: (i) live cells stained green by SYBR-14; (ii) dead cells stained by PI; and (iii) dying cells stained by both SYBR-14 and PI, which had lower fluorescence intensities than live cells for SYBR-14 or dead cells for PI. Percentages of live, dying and dead cells were estimated by drawing three regions on a cytogram of SYBR-14 and PI fluorescences (R1, R2 and R3 in Fig. 1). Such cell discrimination by flow cytometry was previously established for vertebrate and invertebrate sperm (Garner and Johnson 1995; Favret et al. 2010).

The calibration curve, with various ratios of live cells $(0$, 25,75 and $100 \%$ live cells), revealed a very significant correlation between theoretical (dilutions) and measured (flow cytometry) percentages of live cells $\left(R^{2}=0.97\right.$, Fig. 2$)$ and was in good agreement with calibration established by Adams et al. (2003) using the same SYBR-14/PI staining.

\subsection{DNA content estimation}

The integrity of gamete DNA is crucial for the development of the resulting embryo (Lewis and Ford 2012). The 

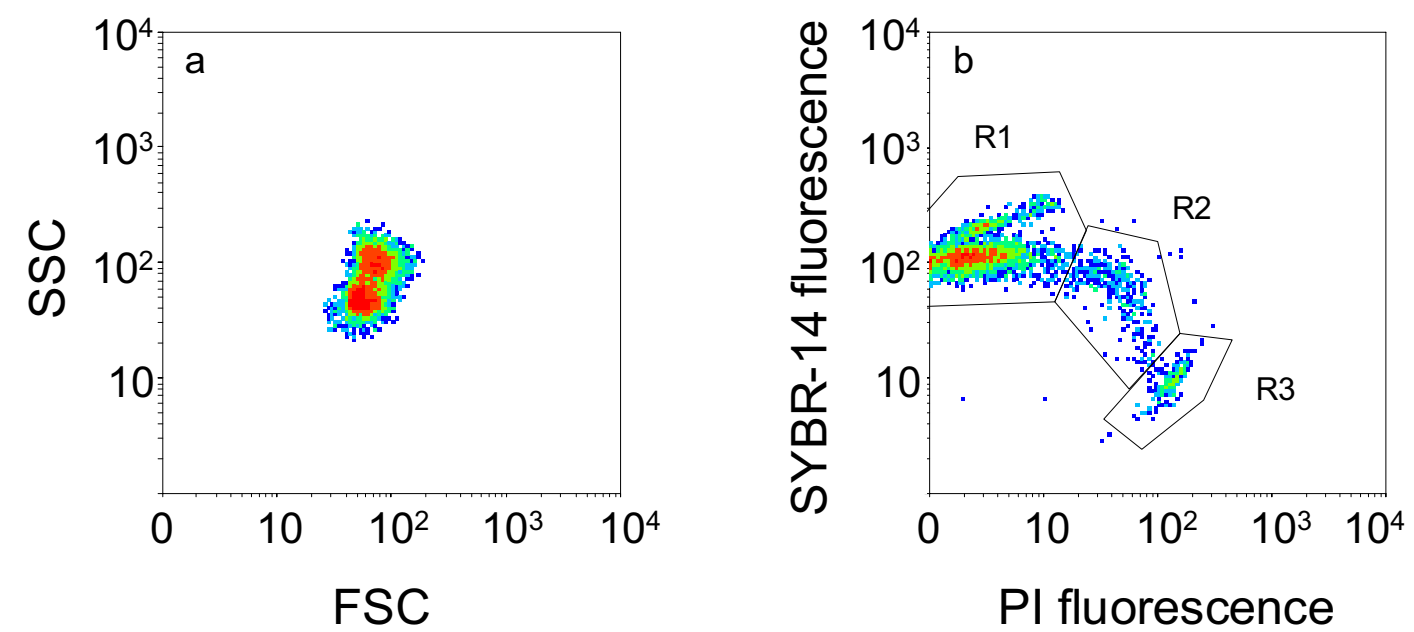

Fig. 1. (a) FSC (relative cell size) vs. SSC (relative cell complexity) cytogram of sperm ( $n>6000$ events). (b) Discrimination of live, dying and dead spermatozoa stained with both SYBR-14 and PI. R1: SYBR-14-stained live cells, R2: SYBR-14- and PI-stained dying cells, and R3: PI-stained dead cells.
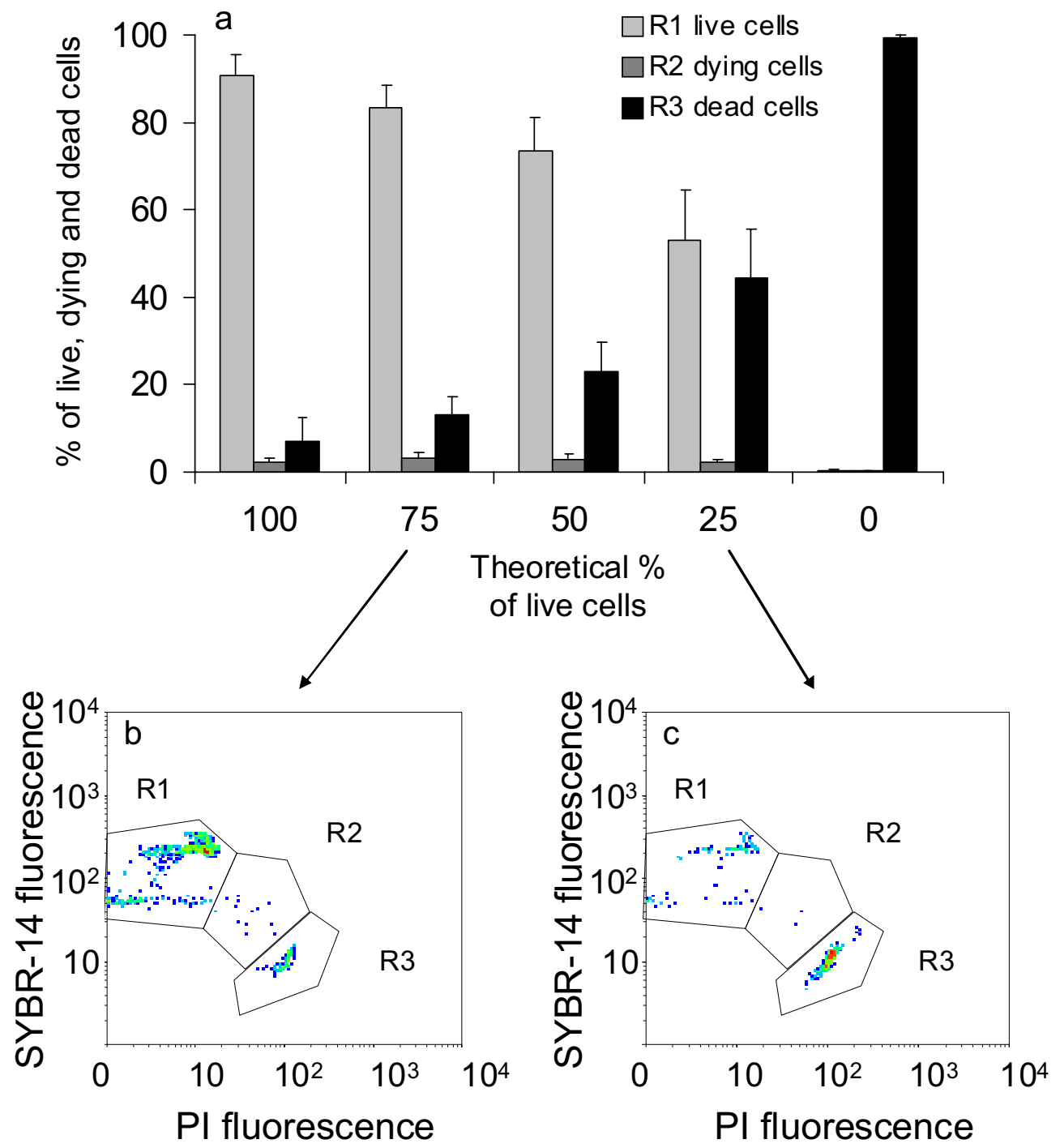

Fig. 2. (a) Percentages of live, dying and dead cells measured with SYBR-14/PI dual staining (mean \pm CI, $n=6$ ). (b) PI fluorescence vs. SYBR-14 fluorescence flow-cytometer density plot of $75 \%$ live sperm and $25 \%$ dead sperm. (c) PI fluorescence vs SYBR-14 fluorescence flow-cytometer density plot of $25 \%$ live sperm and $75 \%$ dead sperm. 


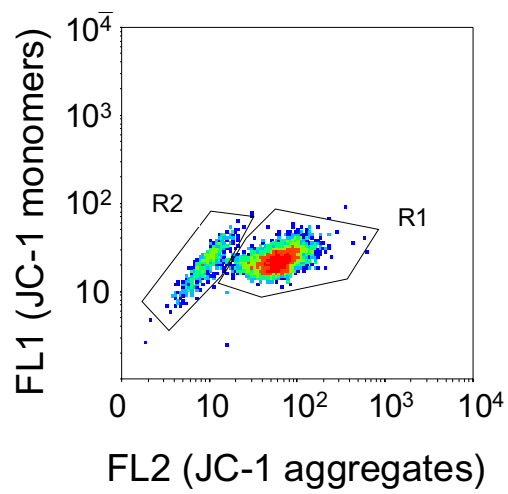

Fig. 3. Flow-cytometer density plot of Pacific oyster sperm stained with JC-1 and analysed for both FL1 (JC-1 monomer form) and FL2 (JC-1 aggregate form) fluorescence. R1: Active cells with FL2 > FL1 and R2: non active cells with FL2 $\approx$ FL1

DNA of mature sperm cells is highly condensed on protamines in a toroid structure, which probably stabilizes and protects the DNA (Silva and Gabella 2006). Nevertheless, DNA fragmentation and damage in live cells may, for instance, occur upon UV exposure (Silva and Gabella 2006).

As SYBR-14, used in viability assessment, binds to DNA of live cells, its fluorescence intensity and pattern can also be used to assess DNA changes. Fluorescence changes are expected to reveal differences in SYBR-14 accessibility to DNA, related to DNA condensation or DNA fragmentation. The coefficient of variation of mean DNA content varied between 1.4 and $7.5 \%$ ( $n=3$ to 7 males), as measured on fully mature oysters (June-July).

\subsection{Mitochondrial membrane potential (MMP)}

Mitochondria are the site of ATP production, the source of energy that allows spermatozoa motility. Mitochondrial membrane potential (MMP) is a sensitive indicator of the energetic status of mitochondria and cells (Reers et al. 1995; Marchetti et al. 2004). MMP was shown to be predictive of in vitro fertilization rates, being higher in a group with high mitochondrial membrane potential (Kasai et al. 2002). For marine organisms, mitochondrial activity was assessed with Rhodamine 123 or MitoTracker ${ }^{\circledR}$ dyes that accumulate in active mitochondria (Ogier de Baulny et al. 1997; Franco et al. 2011).

MMP of oyster sperm was measured using the potentialdependent J-aggregate-forming delocalized lipophilic cation JC-1 because, unlike Rhodamine 123 or MitoTracker ${ }^{\circledR}$ dyes, it can distinguish cells with low mitochondrial activity from cells with high mitochondrial activity (Graham 2001). FL2 orange fluorescence of sperm increases due to active MMP. Orange (FL2) and green (FL1) fluorescences allowed separation of inactive cells, which had similar FL2 and FL1 fluorescences, from active cells, which had higher FL2 than FL1 fluorescence (Fig. 3).

Use of JC-1 for MMP assessment has not yet been validated for mitochondrial activity of sperm from marine organisms. To validate MMP measurement, samples were treated with $100 \mu \mathrm{M}$ CCCP (carbonyl m-chlorophenylhydrazone), an uncoupling agent that abolishes MMP. When oyster sperm was exposed to CCCP, MMP, measured as the FL2/FL1 ratio, significantly decreased 2.5 fold (Fig. 4a). This decrease mainly reflected an FL1 increase from $23 \pm 1$ to $50 \pm 5$ and to a lesser extent an FL2 decrease from $90 \pm 10$ to $78 \pm 7$ in control and CCCP-exposed sperm, respectively (Mean \pm CI, Figs. 4c and e).

Upon $10 \mathrm{mM}$ caffeine incubation, MMP increased significantly by 2 fold (Fig. 4b). This increase resulted from an FL2 increase from $90 \pm 10$ to $131 \pm 12$ and an FL1 decrease from $23 \pm 1$ to $18 \pm 1$ in control and caffeine exposed sperm, respectively (Mean \pm CI, Figs. $4 \mathrm{~d}$ and $\mathrm{f}$ ). This suggests that the activating property of caffeine on oyster sperm may be at least partially mediated through mitochondrial metabolism activation.

\subsection{Morphological and functional characteristics of spermatozoa stripped from Pacific oyster exposed to A. catenella}

\section{Viability}

Viability was assessed on sperm collected from oysters fed A. catenella or H. triquetra (as a control). Percentage of dead and dying cells did not show significant differences between diets (percentages of cells varied from $0.8 \%$ to $3.8 \%$ and 0.6 to $2.7 \%$ for $H$. triquetra and $A$. catenella treatments, respectively). Also, no morphological changes (FSC: relative size, SSC: relative complexity) were observed upon A. catenella exposure (data not shown). Sperm viability has been widely used in mammalian sperm toxicity tests (Lewis and Ford 2012), but has only been tested in a few aquatic invertebrate species (Favret et al. 2010; Akcha et al. 2012). In this study, viability of sperm from oysters exposed to A. catenella was not affected. In a similar experiment, the percentage of dead sperm from $A$. minutum-exposed Pacific oyster broodstock was significantly reduced compared with control conditions (Haberkorn et al., 2010).

\section{DNA content estimation}

DNA content estimation, as measured by SYBR-14 staining, tended to decrease upon exposure of oyster broodstock to A. catenella. SYBR-14 fluorescence of sperm from oysters exposed to H. triquetra $(n=10)$ was $350 \pm 24$ (Mean $\pm \mathrm{CI})$, and fluorescence of sperm from oysters exposed to A. catenella $(n=6)$ was $323 \pm 51($ Mean $\pm \mathrm{CI})$. It can be noted that $A$. catenella exposure resulted in a higher variability of sperm DNA fluorescence compared with those from broodstock fed $H$. triquetra. Coefficient of variation was higher (15.8\%) in A. catenella-exposed oysters than in H. triquetra-exposed oysters $(6.9 \%)$ (Levene's test). These values were also higher than those measured during validation, where coefficients of variation varied from 1.4 to $7.5 \%$ depending on non exposed male samples during maturity period. It thus appears clear that, compared to the $H$. triquetra exposure control, A. catenella exposure leads to DNA modifications. It is speculated that the decrease of DNA content observed with A. catenella exposure may result from some DNA fragmentation or changes in 

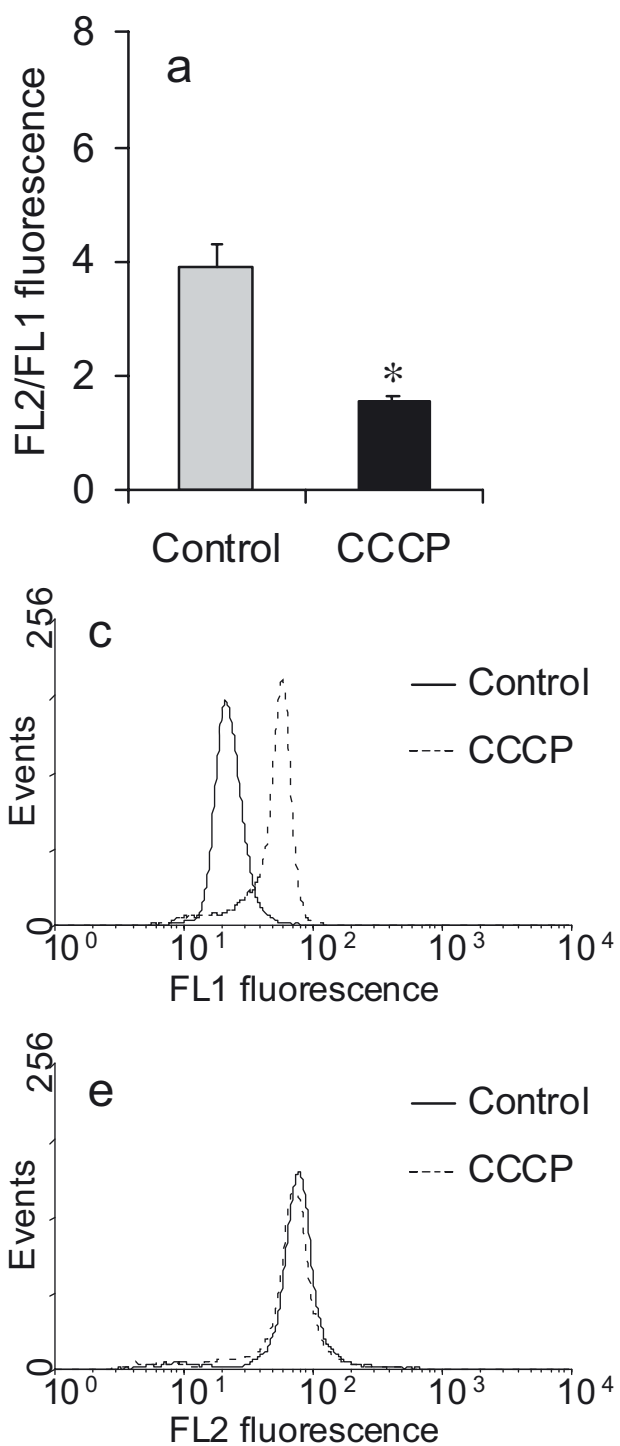
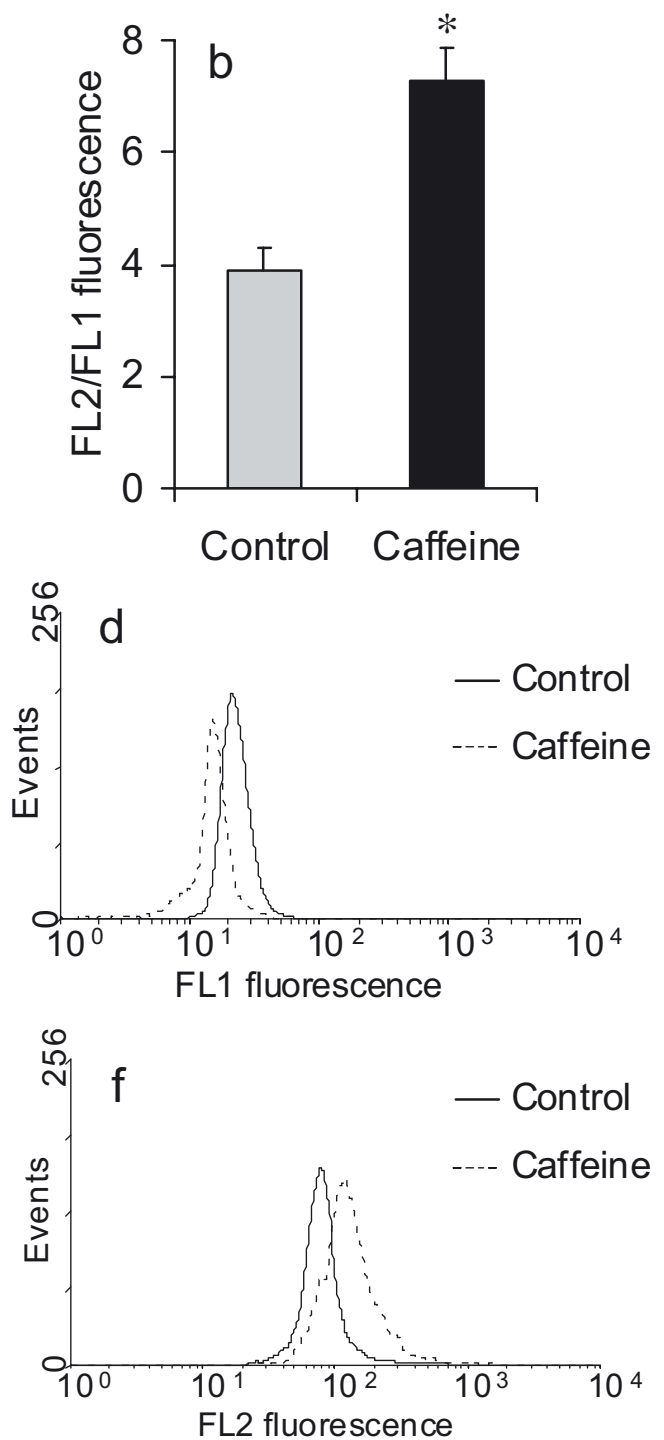

Fig. 4. Mitochondrial membrane potential as measured by FL2/FL1 ratio after JC-1 staining and addition of CCCP (a) or caffeine (b), (mean $\pm \mathrm{CI}, n=6, t$-test, * indicates significant effect at $p<0.05$ ). FL1 fluorescence intensity of one individual sample after addition of CCCP (c) or caffeine (d). FL2 fluorescence intensity of one individual sample after addition of CCCP (e) or caffeine (f). FL2/FL1 ratio of control and caffeine conditions was only measured on active cells (ranging from 65 to $93 \%$ in the samples).

DNA condensation. DNA fragmentation is supposed to be specific to apoptosis (Silva and Gabella 2006) and may thus be somehow induced by $A$. catenella exposure. An increase of DNA staining variability was also observed in sperm from $A$. minutum-exposed Pacific oyster broodstock (Haberkorn et al. 2010). Only a few studies have investigated toxic effects of common environmental contaminants on sperm DNA fluorescence. Lewis and Galloway (2009) demonstrated, for example, that paternal exposure to genotoxins in Mytilus edulis resulted in significant DNA damage in sperm and led to severe developmental abnormalities of the resulting embryos and larvae.

\section{Mitochondrial membrane potential (MMP)}

Mitochondrial membrane potential of active sperm from A. catenella-exposed oysters was significantly higher
(1.5 fold) than those of sperm produced by $H$. triquetraexposed oysters (Fig. 5a). This increase is due to significant decrease of green fluorescence (FL1, Fig. 5b) associated with a non significant increase of orange fluorescence (FL2, Fig. 5c). The non significant difference observed for FL2 orange fluorescence can be associated with the higher variability of orange FL2 fluorescence values of $A$. catenella-exposed oysters (coefficient of variation of $27 \%$ in A. catenella as compared to $18 \%$ in $H$. triquetra-exposed oysters). No difference in percentage of active cells was observed between the two algal exposure treatments.

A similar observation was made on oysters exposed to an A. minutum bloom in the bay of Brest during summer 2012, compared to oysters from a non contaminated site (Aber Benoît, northern Brittany). MMP was significantly higher in sperm of oysters exposed to a natural bloom of A. minutum 

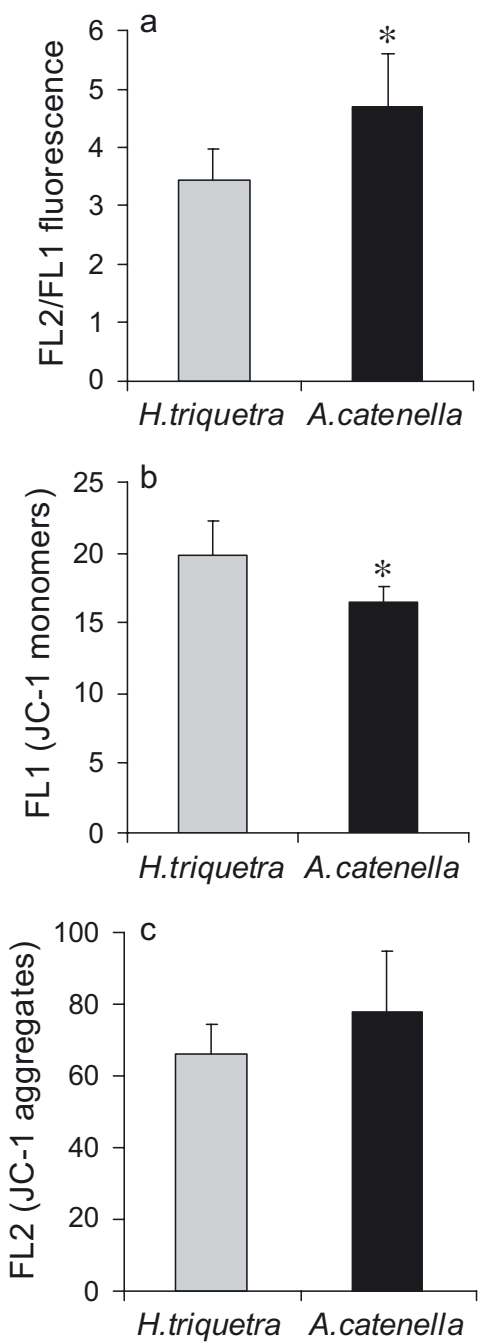

Fig. 5. Mitochondrial membrane potential (MMP) changes of sperm from oysters exposed to $H$. triquetra $(n=9)$ or to A. catenella $(n=6)$, revealed using JC-1 staining. (a) MMP measured as FL2/FL1 fluorescences. (b) FL1 (JC-1 monomer form) fluorescence. (c) FL2 (JC-1 aggregate form) fluorescence. (Mean $\pm \mathrm{CI}, t$-test, * indicates significant differences $p<0.05$ ).

$(p<0.001)$. Moreover, as in the present experimental exposure to A. catenella, no significant difference in percentage of dead spermatozoa or their morphological parameters was observed (data not shown).

Sperm viability appeared to be impacted later than MMP under A. catenella exposure, and was thus not sufficient to assess spermatozoa impairment. Similarly, Lu and Wu (2005) showed that MMP of sea urchin sperm was more sensitive to UVR (ultraviolet radiation) than membrane integrity. Graham (2001) also observed that measuring multiple attributes simultaneously on individual sperm in a population should provide a better estimate of the percentage of sperm that could fertilize an oocyte.

Caffeine inhibits c-Amp-phosphodiesterase activity and leads to increases in the intracellular levels of adenyl cyclasecyclic adenosine 3', 5'-monophosphate (cAMP). Dong et al. (2002) showed that caffeine could induce an increase of sperm motility in Pacific oysters. The activation observed using sperm collected from A. catenella-fed Pacific oyster could be paralleled to above observation of caffeine MMP activation. A decrease of ATP content and motility of sperm from A. minutum-exposed oysters was previously reported by Haberkorn et al. (2010). Further studies on the fine mechanisms regulating energy metabolism and motility in oyster spermatozoa are needed to improve understanding of how HAB exposure may alter energy acquisition and consumption of the cells.

\section{Conclusion}

Measurements of viability and mitochondrial activity of Pacific oyster sperm using flow cytometry were established, fully validated and applied to oyster broodstock exposed to a HAB. These assays allowed it to be demonstrated that a shortterm exposure of oysters to the toxic dinoflagellate A. catenella induced cellular changes, i.e., changes in DNA characteristics and a MMP increase in the sperm produced. Considering the high sensitivity of sperm to chemicals such as DNA intercalants, they could be useful to estimate the impact of phycotoxins or pollutants on reproductive output in impacted coastal areas.

Further studies should focus on complementing the assays developed here (viability, DNA content and MMP) by measurements of reactive oxygen species (ROS), chromatin structure assay, comet assay and acrosomal integrity. Furthermore, embryo development of larvae produced by Pacific oysters exposed to A. catenella should be determined in parallel by quantifying fertilization and larval development rates.

Acknowledgements. The authors would like to thank Malwenn Lassudrie for toxin accumulation data in oysters fed A. catenella and Prof. Aswani Volety for his constructive comments and English corrections.

\section{References}

Adams S.L., Hessian P.A., Mladenov P.V., 2003, Flow cytometric evaluation of mitochondrial function and membrane integrity of marine invertebrate sperm. Invert. Reprod. Dev. 44, 45-51.

Akcha F., Spagnol C., Rouxel J., 2012, Genotoxicity of diuron and glyphosate in oyster spermatozoa and embryos. Aquat. Toxicol. 106-107, 104-113.

Anderson D.M., Alpermann T.J., Cembella A.D., Collos Y., Masseret Et, Montresor M., 2012, The globally distributed genus Alexandrium: Multifaceted roles in marine ecosystems and impacts on human health. Harmful Algae 14, 10-35.

Basti L., Go, J., Higuchi, K., Nagai K., Segawa S., 2011, Effects of the toxic dinoflagellate Heterocapsa circularisquama on larvae of the pearl oyster Pinctada fucata martensii (Dunker, 1873). J. Shellfish Res. 30, 177-186.

Basti L., Nagai K., Tanaka Y., Segawa S., 2013, Sensitivity of gametes, fertilization, and embryo development of the Japanese pearl oyster, Pinctada fucuta martensii, to the harmful dinoflagellate, Heterocapsa circularisquama. Mar Biol. 160, 211-219.

Bricelj V.M., MacQuarrie S.P., 2007, effects of brown tide (Aureococcus anophagefferens) on hard clam, Mercenaria mercenaria, larvae and implications for benthic recruitment. Mar Ecol. Prog. Ser. 333, 147-159. 
Collos Y., Gagné C., Laabir M, Vaquer A., Cecchi P, Souchu P., 2004, Nitrogenous nutrition of Alexandrium catenella (Dinophyceae) in cultures and in Thau lagoon, southern France. J. Phycol. 40, 96-103.

Cordelli E., Eleuteri P., Leter G., Rescia M., Spanò M., 2005, Flow cytometry applications in the evaluation of sperm quality: semen analysis, sperm function and DNA integrity. Contraception 72 . 273-279.

Dong Q., Eudeline B., Allen Jr. S.K., Tiersch T.R., 2002, Factors affecting sperm motility of tetraploid Pacific oysters. J. Shellfish Res. 21, 719-723.

Erard-Le Denn E., Morlaix M., Dao J.C., 1990, Effects of Gyrodinium cf. aureolum on Pecten maximus (post larvae, juveniles and adults). In: Graneli E., Sundstrom B, Edler L., Anderson D.M. (Eds.) Toxic Marine Phytoplankton, Elsevier 132-136.

Favret P., Lynn J.W., 2010, Flow-cytometric analyses of viability biomarkers in pesticide-exposed sperm of three aquatic invertebrates. Arch. Environ. Contam. Toxicol. 58, 973-84.

Flajshans M., Cosson J., Rodina M., Linhart O., 2004, The application of image cytometry to viability assessment in dual fluorescence-stained fish spermatozoa. Cell Biol. Int. 28, 955-959.

Franco A., Kellner K., Mathieu M., Lelong C., Goux D., HeudeBrethelin C., 2011, Male germ cells of the Pacific oyster Crassostrea gigas: flow cytometry analysis, cell sorting and molecular expression. Aquat. Living Resour. 24, 237-245.

Garner D.L., Johnson L.A., Yue S.T., Roth B.L., Haugland R.P., 1994, Dual DNA staining assessment of bovine sperm viability using SYBR-14 and propidium iodide. J. Androl. 15, 620-629.

Garner D.L., Johnson L.A., 1995, Viability assessment of mammalian sperm using SYBR-14 and propidium iodide. Biol. Reprod. 53, 276-284

Gillan L., Evans G., Maxwell W.M.C., 2005, Flow cytometric evaluation of sperm parameters in relation to fertility potential. Theriogenology 63, 445-457.

Graham J.K., 2001, Assessment of sperm quality: a flow cytometric approach. Anim. Reprod. Sci. 68, 239-24.

Granmo A., Havenhand J., Magnusson K, Svane I., 1988, Effects of the planktonic flagellate Chrysochromulina polylepis Manton et Park on fertilization and early development of the ascidian Ciona intestinalis (L.) and the blue mussel Mytilus edulis L. J. Exp. Mar. Biol. Ecol. 124, 65-71.

Guillard R.R.L. and Hargraves P.E., 1993, Stichochrysis immobilis is a diatom, not a chrysophyte. Phycologia 32, 234-236.

Haberkorn H., Lambert C., Le Goïc N., Moan J., Suquet M., Guéguen M., Sunila I., Soudant P., 2010, Effects of Alexandrium minutum exposure on nutrition-related processes and reproductive output in oysters Crassostrea gigas. Harmful Algae 9, 427-439.

Haberkorn H., Tran D., Massabuau J-C., Ciret P., Savar V., Soudant P., 2011, Relationship between valve activity, microalgae concentration in the water and toxin accumulation in the digestive gland of the Pacific oyster Crassostrea gigas exposed to Alexandrium minutum. Mar. Pollut. Bull. 62, 1191-1197.

Hégaret H., Brokordt K.B., Gaymer C.F., Lohrmann K.B., Garcia C., Varela D., 2012, Effects of the toxic dinoflagellate Alexandrium catenella on histopathogical and escape responses of the Northern scallop Argopecten purpuratus. Harmful Algae 18, 74-83.

Kasai T., Ogawa K., Mizuno K., Nagai S., Uchida Y., Ohta S., Fujie M., Suzuki K., Hirata S, Hoshi K., 2002, Relationship between sperm mitochondrial membrane potential, sperm motility, and fertility potential. Japan Asian J. Androl. 4, 97-103.
Leverone J., Blake N.J., Pierce R.H., Shumway S.E., 2006, Effects of the dinoflagellate Karenia brevis on larval development in three species of bivalve mollusk from Florida. Toxicon 48, 75-84.

Lewis C. and Galloway T., 2009, Reproductive consequences of paternal genotoxin exposure in marine invertebrates. Environ. Sci. Technol. 43, 928-933.

Lewis C., Ford A.T., 2012, Infertility in male aquatic invertebrates: a review. Aquat. Toxicol. 120-121, 79-89.

Lilly E.L., Kulis D.M., Gentien P., Anderson D.M., 2002, Paralytic shellfish poisoning toxins in France linked to human-introduced strain of Alexandrium catenella from the western Pacific: evidence from DNA and toxin analysis. J. Plankton Res. 24, 443-452.

Lu X.Y. and Wu R.S.S., 2005, UV induces reactive oxygen species, damages sperm, and impairs fertilization in the sea urchin Anthocidaris crassispina. Mar. Biol. 148, 51-57.

Marchetti C., Jouy N., Leroy-Martin B., Defossez A., Formstecher P., Marchetti P., 2004, Comparison of four fluorochromes for the detection of the inner mitochondrial membrane potential in human spermatozoa and their correlation with sperm motility. Hum. Reprod. 19 2267-2276.

Mukai C., Okuno M., 2004, Glycolysis plays a major role for adenosine triphosphate supplementation in mouse sperm flagellar movement. Biol. Reprod. 71, 540-547.

Navarro, J.M., Contreras A.M., 2010, An integrative response by Mytilus chilensis to the toxic dinoflagellate Alexandrium catenella. Mar. Biol., 157, 1967-1974.

Nice H.E., 2005, Sperm motility in the Pacific oyster (Crassostrea gigas) is affected by nonylphenol. Mar. Pollut. Bull. 50, 1668-1674.

Ogier de Baulny B., LeVern Y., Kerboeuf D., Maisse G., 1997, Flow cytometric evaluation of mitochondrial activity and membrane integrity in fresh and cryopreserved rainbow trout (Onchorhynchus mykiss) spermatozoa. Cryobiology 34, 141-149.

Paniagua-Chavez C.G., Jenkins J., Segovia M., Tiersch T.R., 2006, Assessment of gamete quality for the eastern oyster (Crassostrea virginica) by use of fluorescent dyes. Cryobiology 53, 128-138.

Reers M., Smiley S.T., Mottola-Hartshorn C., Chen A., Lin M., Chen L.B., 1995, Mitochondrial membrane potential monitored by JC-1 dye. Methods Enzymol. 260, 406-414.

REPHY Ifremer, espèces toxiques et toxines : Zones touchées par une interdiction de vente des coquillages 1992-2001. http://envlit. ifremer.fr/var/envlit/storage/documents/dossiers/toxines10ans/ pdf/secteursfermes.pdf.

Silva P.F.N., Gadella B.M., 2006, Detection of damage in mammalian sperm cells. Theriogenology 65, 958-978.

Summerson H.C., Peterson C.H., 1990, Recruitment failure of the Bay Scallop, Argopecten irradians concentricus, during the first red tide, Ptychodiscus brevis, outbreak recorded in North Carolina. Estuaries 13, 322-331.

Tang Y.Z., Gobler C.J., 2009, Cochlodinium polykrikoides blooms and clonal isolates from the northwest Atlantic coast cause rapid mortality in larvae of multiple bivalve species. Mar. Biol. 156, 2601-2611.

Thomas C.A., Garner D.L., DeJarnette J.M., Marshall C.E., 1998, Effect of cryopreservation of bovine sperm organelle function and viability as determined by flow cytometry. Biol. Reprod. 58.3.786.

Whedon W.F., Kofoid C.A., 1936, Dinoflagellata of the San Francisco region. I. On the skeletal morphology of two new species, Gonyaulax catanella and G. acatenella. Univ. Calif. Publs. Zool. $41,25-34$. 